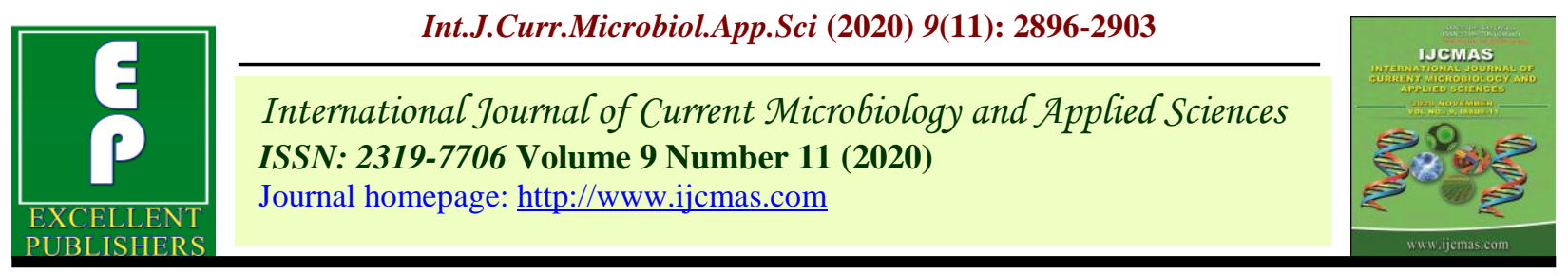

Original Research Article

https://doi.org/10.20546/ijcmas.2020.911.351

\title{
Effect of Cytokinin on Fruit Crops
}

\author{
Anubhav Biswal* and Chandan Kumar Rout \\ Lovely Professional University, Punjab, India \\ *Corresponding author
}

\begin{abstract}
A B S T R A C T
Keywords

BAP, TDZ, BA, CPPU,

Morphogenesis,

Kinetin, Senescence

Article Info

Accepted:

20 October 2020

Available Online:

10 November 2020

The word for cytokinin is a generic name and naturally occurring substances that are known to promote cell division. The term cytokinin was proposed by Letham in 1963. It is also known to delay senescence. In corn the first naturally occurring cytokinin was found and is named as zeatin. The most widely distributed cytokinins are the synthetic benzyladenine and kinetin. The natural cytokinin found in apical root meristem, inflorescences and developing fruits. The role of cytokinin in plant is cell division, lateral bud development, delaying senescence, Shoot formation or organogenesis, parthenocarpy fruit production, etc. High cytokinin and low auxin could promote formation of shoot buds.
\end{abstract}

\section{Introduction}

Phytohormones produced naturally in higher plants, controlling growth or other physiological functions at a site remote from its place of production and active in minute amounts. plant growth regulators contain naturally occurring phytohormones, their chemical analogs, hormone sensitivity, hormone releasing agents, altering agents and hormone synthesis inhibitors (Hajam et al., 2017). Plant growth regulators are auxins, gibberellins, cytokinin, ethylene, growth retardants and growth inhibitors. Cytokinin plays a key role in the life of higher plant. Main roles of cytokinin are cell division, delay senescence, organogenesis, induce flowering in short day plant, axillary bud formation, etc. The most widely distributed cytokinins are the synthetic benzyladenine and kinetin. The leaves senescence usually occurs with loss of chlorophyll and rapid breakdown of proteins. By kinetin treatment Senescence can be postponed to several days by improving RNA synthesis followed by protein synthesis. High cytokinin and low auxin could promote formation of shoot buds. Plants accumulate solutes very actively with the help of Cytokinin and also help in solute translocation in phloem. Recent studies proved that other phytohormones like cytokinin, may also affect stomatal openings (Acharya and Assmann, 2009). Peleg and Blumwald (2011) reported that cytokinin plays very important role as antagonistic during stress conditions. It has been 
hypothesized that $\mathrm{CK}$ acts as undesirable regulator against abiotic stress signaling (Nishiyama et al., 2013).

\section{Effect of Cytokinin on different fruit crops}

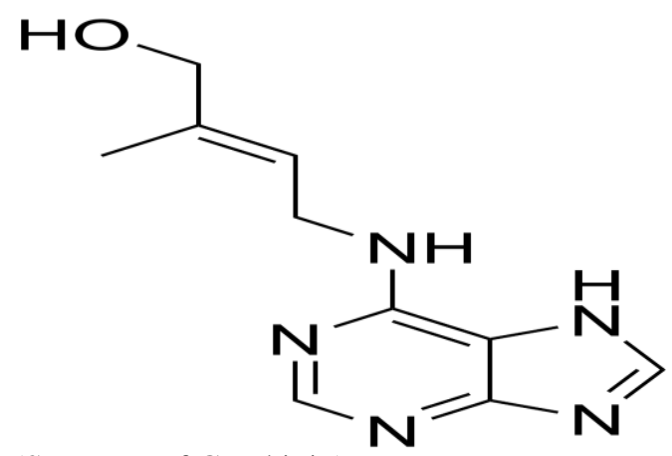

(Structure of Cytokinin)

\section{Apple}

Tan et al., (2019) observed on role of cytokinin on outgrowth of auxiliary buds in apple and he opined that high content cytokinin present in more branching mutant type and in wild type exogenous application of ck promotes axillary bud out growth. Magyaretal. (2010) opined that highest regeneration occurs in pretreated apple explant with BA than that of treatment free explant.

Stern et al., (2006) concluded that in apple cv. Golden delicious application of CPPU @ $10 \mathrm{mg} / 1$ or BA @ $50 \mathrm{mg} / 1$ after 2weeek of full bloom shows positive impact on fruit size with no negative impact on yield, fruit shape, seed number. Yuan and Greene (2000) achieved that application of BA in apple increase the endogenous cytokinin (zeatin) which promoted maximum cell division.

Cook et al., (2001) opined that in apple outgrowth of auxiliary bud occurs during spring by following winter dormancy and this spring bud burst promoted by cytokinin from the shoot. Stern et al., (2003) obtained that in warm condition BA shows significant effect on fruit size of apple var. Royal gola.
Pear

Chen et al (2012) obtained that application of CPPU 10ppm and BA 30PPM increases fruit size in pear. Flashiman et al., (2001) and Stern et al., (2002) achieved that use of CPPU and BA have significant effect on pear cv. Spadona and coscia in respect to weight and size of the fruit. Kodota et al., (2003) observed effect of different concentration of cytokinin on pear explant and found that highest shoot multiplication achieved by

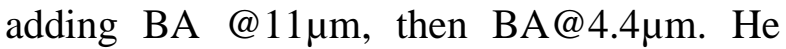
also opined that greater hyper-hydricity caused by TDZ and CPPU than BA and kinetin. Sing et al., (2004) concluded that $10 \mathrm{ppm}$ BA application increase leaf chlorophyll contains in pear leaf, so leaf senescence delay.

Flaishman et al., (2001) obtained that application of CPPU @ 10-20ppm on low cilling pear cv. Spadona and cosita 2 weeks after full bloom shows positive impact on fruit size with no negative impact in relation to fruit shape and yield. He also compared different time of application of CPPU and opined that cell division at early stage of fruit development have a major role on final fruit size, so it is significant to apply CPPU after 2 week of full bloom than one month after blooming. Similarly, Zhang et al., (2007) opined that at early stage of fruit growth CPPU stimulate effective for cell division.

Shargal et al., (2006) observed that application of CPPU or TDZ caused the phase of cell division in parenchyma cell in pulp which helped to achieved better fruit diameter.

Stern et al., (2003) obtained that application of BA on pear cv. Cosica shows significant effect on fruit size with no negative aspect.

Zihang et al., (2008) investigated that application of CPPU induce parthenocarpic in 
Japanese pear. He also opined that CPPU not only increased the fruit set percentage but also increase the fruit size in all rosaceae family.

\section{Prunus species}

Tsafouros et al., (2018) concluded that BA has positive impact on proliferation of shoot in prunus species explant. Alanagh et al., (2010) achieved that BA has significant effect on rootstock GF-677. Similar observation by Andreu et al., (2005) on Adesoto101 rootstock.

Nowak et al., (2002) achieved that number of adventitious bud obtain on media containing TDZ or BAP and numerous bud per explant increases.

\section{Mango}

Notodiamedio (2000) suggested that application of CPPU 10ppm promotes highest fruit retention, number of fruits per cluster, fruit weight and leaf area.

El-Badawy et al., (2013) observed that highest level of kinetin promotes highest stem diameter, number of branches per plant, number of leaves per plant. In addition, it also reduces the risk of vegetative malformation.

\section{Kiwi fruit}

Akbas et al., (2007) investigated that MS medium supplement with BAP @ $0.5 \mathrm{mg} / 1$ shows highest shoot multiplication than that supplement with kinetin. Caboni et al., (2001) observed that BA $(4.4 \mu \mathrm{m})$ helps shoot formation from kiwi fruit explant. Moncalean et al., (2001) suggested that on kiwi fruit BA has positive impact on different phase of micropropagation and regulate further development of the regenerants.

Ainalidou et al., (2016) observed that application of CPPU stimulate fruit growth by enlarging small cells. He also opined that apart from the size development CPPU disturb the ethylene production in kiwi fruit by delaying softening of central placenta and indirectly increased shelf life of fruit. Prado et al., (2007) found that better shoot multiplication achieve in presence of Zeatin @ 2-3 $\mu \mathrm{m}$. Ainalidou et al., (2015) opined that CPPU provide superior quality of kiwifruit under good pollination condition. Patterson et al., (1993) observed that kiwi fruit dipping in CPPU shows more greener than untreated fruit.

Yingning et al., (2010) found that successful Shoot multiplication obtained by supplement of IBA@0.05-0.1mg/l or BA@0.2mg/l in the medium.

\section{Cherry}

Guak et al., (2005) observed that application of promalin (250ppm BA + 1000ppm GA) delay the leaf senescence in sweet cherry. Zhang et al., (2011) achieved that application of CPPU 30days after full bloom shows significant effect on fruit weight.

\section{Citrus}

Rathore et al., (2007) observed that highest shoot multiplication achieved successfully in MS medium amended with BAP. Singh et al., (2006) achieved that in kinnow explant culture maximum number of flowers per culture achieved by MS medium supplement with kinetin $0.2 \mathrm{mg} / \mathrm{l}$. Saini et al., (2010) obtained that MS medium amended with BA@0.5mg/l shows highest bud per explant in rough lemon.

Khalid et al., (2012) observed that application in kinnow BA @ 30g/l and kinetin at the time of fruit setting shows positive impact of fruit juice. He also observed that highest reducing sugar obtained by application of kinetine @ $20 \mathrm{mg} / \mathrm{l}$ at the timeof flowering. 


\section{Lychee}

Dhua et al., (2003) found that spraying of kinetin@25mg/l improves the fruit weight, in addition to delaying fruit ripening by reducing ethylene production.

\section{Grapevine}

Amiri et al., (2019) found that BA (1.5mg/l) treat grape vine explant showed highest nodes per explant than treated free explant. Jaskani et al., (2008) opined that media containing BA helps highest branching in explant. Zabadal et al., (2006) obtained that at every concentration of CPPU $(5,10,15 \mathrm{mg} / \mathrm{l})$ shows significant effect on berry mass and firmness whereas concentration @ 5 and 10mg/l give additional effect i.e. promotes better berry diameter.

Fig

Chai et al., (2019) achieved that applied CPPU $(25 \mathrm{mg} / \mathrm{l})$ at the time of anthesis promotes parthenocarpy fruit.

\section{Pomegranate}

Sharma and Belsare (2011) obtained that foliar spray of CPPU 5ppm in month of Aprilincrease fruit size, juice content of pomegranate where as Supe and Marbhal (2008) observed that BA application promotes maximum fruit drop on pomegranate var. mirdula.

\section{Phalsa}

Debnath et al., (2011) achieved that 10ppm kinetin increases shelf life of phalsa.

\section{Guava}

Debnath et al., (2011) recorded maximum ascorbic acid and TSS in guava treated with 100ppm BA. Mishra et al., (2005) opined that MS medium contain BAP @ 3mg/l promotes shoot bud proliferation.

\section{Avocado}

Benomoualem et al., (2001) investigated that preharvest treatment of Avocado cv.fuerte with TDZ $(10 \mathrm{mM})$ or BAP $(40 \mathrm{mM})$ induce resistance against fungus. He also opined that cv. Fttnger preharvest treatment with BA caused delaying of fruit softening.

In conclusion the exogenous application of cytokinin might, therefore, act as a powerful tool not only for enhancing cell division, fruit quality and weight and size but also in combating the ill effects generated by various biotic and abiotic stresses in plants in the near future.

\section{References}

Abido AIA, Aly MAM, Hassanen SA, Rayan GA (2013) In vitro propagation of grapevine (Vitis vinifera L.) Muscat of Alexandria cv. for conservation of endangerment. Middle East J Sci Res 13:28-37.

Acharya, B. and Assmann, S. 2009. Hormone interactions in stomatal function. Plant Molecular Biology69:451-462.

Ainalidou, A., Karamanoli, K., MenkissogluSpiroudi, U., Diamantidis, G., and Matsi, T. (2015). CPPU treatment and pollination: Their combined effect on kiwifruit growth and quality. Scientia Horticulturae, 193, 147-154.

Ainalidou, A., Tanou, G., Belghazi, M., Samiotaki, M., Diamantidis, G., Molassiotis, A., and Karamanoli, K. (2016). Integrated analysis of metabolites and proteins reveal aspects of the tissue-specific function of synthetic cytokinin in kiwifruit development and ripening. Journal of proteomics, 143, 318-333.

Akbaş, F. A., Işikalan, C., Namli, S. Ü. R. E. Y. Y. A., and Başaran, D. A. V. U. T. (2007). Micropropagation of kiwifruit (Actinidia deliciosa). International 
Journal of Agriculture and Biology, 9(3), 489-493.

Alanagh EN, Garoosi GA, Haddad R (2010). The effect of PGRs on in vitro shoot multiplication of GF677 hybrid (Prunus persica $\times P$. amygdalus) rootstock on GNH medium. Iranian Journal of Genetics and Plant Breeding 1:34-43.

Amiri, S., Mohammadi, R., and Akbari, R. (2019). The Effects of Cytokinin and Auxin Interactions on Proliferation and Rooting of Seedless Grapevine (Vitis vinifera L.) cv. 'Sultanine'. ErwerbsObstbau, 61(1), 85-92.

Andreu P, Marin JA (2005). In vitro culture establishment and multiplication of the Prunus rootstock 'Adesoto 101' (P. insititia L.) as affected by the type of propagation of the donor plant and by the culture medium composition. Scientia Horticulturae 106:258-267.

Beno-Moualem, D., Vinokur, Y., and Prusky, D. (2001). Cytokinins Increase Epicatechin Content and Fungal Decay Resistance in Avocado Fruits. Journal of Plant Growth Regulation, 20(1).

Bisht, T. S., Rawat, L., Chakraborty, B., and Yadav, V. (2018). A Recent Advances in Use of Plant Growth Regulators (PGRs) in Fruit Crops-A Review.

Brewer, P. B., Dun, E. A., Ferguson, B. J., Rameau, C., and Beveridge, C. A. (2009). Strigolactone acts downstream of auxin to regulate bud outgrowth in pea and Arabidopsis. Plant Physiol. 150, 482-493. doi: 10.1104/pp.108. 134783

Caboni, E., Biasi, R., Delia, G., and Tonelli, M. (2009). Effect of CPPU on in vitro axillary shoot proliferation and adventitious shoot regeneration in kiwifruit. Plant Biosystems, 143(3), 456461.

Chai, P., Dong, S., Chai, L., Chen, S., Flaishman, M., and Ma, H. (2019). Cytokinin-induced parthenocarpy of San Pedro type fig (Ficus carica L.) main crop: explained by phytohormone assay and transcriptomic network comparison. Plant molecular biology, 99(4-5), 329346.

Chen, X., Bao, J., Chen, Y., Chen, T., Zhang, C. And Huang, X. 2012. Effect of hormone treatment on deformed fruit development in pear. African journal of biotechnology 11(44): 10207-10209.

Chen, X., Bao, J., Chen, Y., Chen, T., Zhang, C. And Huang, X. 2012. Effect of hormone treatment on deformed fruit development in pear. African journal of biotechnology 11(44): 10207-10209.

Cook, N. C., Bellstedt, D. U., and Jacobs, G. (2001). Endogenous cytokinin distribution patterns at budburst in Granny Smith and Braeburn apple shoots in relation to bud growth. Sci. Horticult. 87, 53-63. doi: 10.1016/s0304-4238(00) 00161-8

Debnath A, Vanajalatha K, Momin U, Reddy M. Effect of NAA, GA3, kinetin and ethrel on yield and quality in phalsa (Grewia sub-inaequalis DC). The Asian J of Hort. 2011; 6:474-477.

Dhua, R. S., Roychoudhury, R., Ray, S. K. D., and Kabir, J. (2003, August). Staggering the lychee fruit harvest. In II International Symposium on Lychee, Longan, Rambutan and other Sapindaceae Plants 665 (pp. 347-354).

El-Badawy, H. E. M., and El-Aal, M. A. (2013). Physiological response of Keitt mango (Mangifera indica L.) to kinetin and tryptophan. Journal of Applied Sciences Research, 9(8), 4617-4626.

FLAISHMAN, M. A., SHARGAL, A. and STERN, R. A. (2001). The synthetic cytokinin CPPU increases fruit size and yield of 'Spadona' and 'Costia' pear (Pyrus communis L.). Journal of Horticultural Science and Biotechnology, 76, 145-149.

Flaishman, M., Amihai Shargal, A. S., and Raphael, S. (2001). The synthetic 
cytokinin CPPU increases fruit size and yield of 'Spadona' and 'Costia' pear (Pyrus communis L.). The Journal of Horticultural Science and Biotechnology, 76(2), 145-149.

Guak, S., Beulah, M., Neilsen, D., Quamme, H. A., and Looney, N. E. (2005). Effects of urea and plant bioregulators (Ethephon and Promalin) on tissue nitrogen levels, cold hardiness, and cropping of sweet cherry trees. Acta Hort, 667, 453-460.

Hajam, M. A., Hassan, G. I., Bhat, T. A., Bhat, I. A., Rather, A. M., Parray, E. A., Wani, M. A., and Khan, I. F. 2017. Understanding plant growth regulators, their interplay: For nursery establishment in fruits. International Journal of Chemical Studies, 5(5): 905910.

Jaskani MJ, Abbas H, Sultana R, Khan MM, Qasim M, Khan IA. (2008) Effect of growth hormones on micropropagation of Vitis vinifera L. cv. Perlette. Pakistan J Bot 40:105-109

Kadota, M., and Niimi, Y. (2003). Effects of cytokinin types and their concentrations on shoot proliferation and hyperhydricity in in vitro pear cultivar shoots. Plant Cell, Tissue and Organ Culture, 72(3), 261-265.

Khalid, S., Malik, A. U., Khan, A. S., and Jamil, A. (2012). Influence of exogenous applications of plant growth regulators on fruit quality of young'kinnow'mandarin (Citrus nobilis $\times$ C. deliciosa) trees. International Journal of Agriculture and Biology, 14(2).

Kumari, S., Bakshi, P., Sharma, A., Wali, V. K., Jasrotia, A., and Kour, S. (2018). Use of Plant Growth Regulators for Improving Fruit Production in Sub Tropical Crops. Int. J. Curr. Microbiol. App. Sci, 7(3), 659-668.

Magyar-Tábori, K., Dobránszki, J., da Silva, J. A. T., Bulley, S. M., and Hudák, I.
(2010). The role of cytokinins in shoot organogenesis in apple. Plant Cell, Tissue and Organ Culture (PCTOC), 101(3), 251-267.

Mishra, M., Chandra, R., Pati, R., and Bajpai, A. (2005, December). Micropropagation of guava (Psidium guajava L.). In I International Guava Symposium 735 (pp. 155-158).

Mok, D. W., and Mok, M. C. (2001). Cytokinin metabolism and action. Annual review of plant biology, 52(1), 89-118.

Moncaleán, P., Rodríguez, A., and Fernández, B. (2001). In vitro response of Actinidia deliciosa explants to different BA incubation periods. Plant cell, tissue and organ culture, 67(3), 257-266.

Nishimura, N., Hitomi, K., Arvai, A.S., Rambo, R.P., Hitomi, C., Cutler, S.R., Schroeder, J.I. and Getzoff, E.D. 2009. Structural mechanism of abscisic acid binding and signaling by dimeric PYR1. Science326 (5958): 1373-1379.

Notodimedjo, S. 2000.Effect of GA3, NAA and CPPU on fruit retention, yield and quality of mango (cv. ARUMANIS) in East Java. Acta Hort., 509(2): 587-600

Nowak, B., and Miczyński, K. (2002). The Course and Efficiency of organogenesis on leaf explants of plum: $\mathrm{E}^{*},(5 . \$=:<$. à $\$$ Prunus domestica L.) induced by cytokinins. Biotechnology, 5(1).

Patterson, K. J., Mason, K. A., and Gould, K. S. (1993). Effects of CPPU (N-(2-chloro-4-pyridyl)-N'-phenylurea) on fruit growth, maturity, and storage quality of kiwifruit. New Zealand journal of crop and horticultural science, 21(3), 253-261.

Peleg, Z., Reguera, M., Tumimbang, E., Walia, H. and Blumwald, E. 2011. Cytokinin-mediated source/sink modifications improve drought tolerance and increases grain yield in rice under water-stress. Plant Biotechnology 
Journal9(7): 747-758.

Prado, M. J., Gonzalez, M. V., Romo, S., and Herrera, M. T. (2007). Adventitious plant regeneration on leaf explants from adult male kiwifruit and AFLP analysis of genetic variation. Plant cell, tissue and organ culture, 88(1), 1-10.

Rathore, J. S., Rathore, M. S., Singh, M., Singh, R. P., and Shekhawat, N. S. (2007). Micropropagation of mature tree of Citrus limon.

safouros, A., and Roussos, P. A. (2019). First Report of Krymsk® 5 (cv. VSL 2) Cherry Rootstock In Vitro Propagation: Studying the Effect of Cytokinins, Auxins and Endogenous Sugars. Notulae Botanicae Horti Agrobotanici ClujNapoca, 47(1), 152-161.

Saini, H. K., Gill, M. S., and Gill, M. I. S. (2010). Direct shoot organogenesis and plant regeneration in rough lemon (Citrus jambhiri Lush.).

Sebastian, K., Arya, M.S., Reshma, U.R., Anaswara, S.J., and Thampi, S.S. (2019). Impact of Plant Growth Regulators on Fruit Production.

Shah, S. T., Zamir, R., Ahmad, J., Ali, H., and Lutfullah, G. (2008). In vitro regeneration of plantlets from seedlings explants of guava (Psidium guajava L.) cv. Safeda. Pak J Bot, 40(3), 1195-1200.

Shargal, A., Golobovich, S., Yablovich, Z., Shlizerman, L. A., Stern, R. A., Grafi, G. and Flaishman, M. A. (2006). Synthetic cytokinins extend the phase of division of parenchyma cells in developing pear (Pyrus communis L.) fruits. The Journal of Horticultural Science and Biotechnology, 81(5), 915920.

Sharma N, Belsare C. Effect of plant bioregulators and nutrients on fruit cracking and quality in pomegranate (Punica granatum L.) ' $\mathrm{G}-137$ ' in Himachal Pradesh. Acta Horticulture. 2011; 890:347-352
Singh K. Effect of plant growth regulators on vegetative growth, flowering, fruit set and fruit quality of Baggughosha pear. MSc. Thesis. Dr YS Parmar University of Horticulture and Forestry, Nauni, Solan, HP, India, 2004.

Singh, B., Sharma, S., Rani, G., Virk, G. S., Zaidi, A. A., and Nagpal, A. (2006). In vitro flowering in embryogenic cultures of Kinnow mandarin (Citrus nobilis Lour C. deliciosa Tenora). African Journal of Biotechnology, 5(16).

Stern, A. R., Ben-Arie, R., Applebaum, S., and Flaishman, M. (2006). Cytokinins increase fruit size of 'Delicious' and 'Golden Delicious'(Malus domestica) apple in a warm climate. The Journal of Horticultural Science and Biotechnology, 81(1), 51-56.

Stern, R. A., and Flaishman, M. A. (2003). Benzyladenine effects on fruit size, fruit thinning and return yield of 'Spadona' and 'Coscia' pear. Scientia horticulturae, 98(4), 499-504.

Stern, R. A., Ben-Arie, R., Neria, O., and Flaishman, M. (2003). CPPU and BA increase fruit size of 'Royal Gala'(Malus domestica) apple in a warm climate. The Journal of Horticultural Science and Biotechnology, 78(3), 297-302.

Supe VS, Marbhal SK. Effect of plant growth substances on fruit size of pomegranate (Punica granatum L.) cv. Mridula. The Asian Journal of Horticulture. 2008; 3:18- 20.

Tan M, Li G, Chen X, Xing L, Ma J, Zhang $D$, Ge H, Han M, Sha $G$ and An N (2019) Role of Cytokinin, Strigolactone, and Auxin Export on Outgrowth of Axillary Buds in Apple. Front. Plant Sci. 10:616. doi: 10.3389/fpls.2019.00616.

Ying-Ning, Z. O. U. (2010). Micropropagation of Chinese plum (Prunus salicina Lindl.) using mature stem segments. Notulae Botanicae Horti Agrobotanici Cluj-Napoca, 38(3), 214- 
218.

YUAN, R. and GREENE, D. W. (2000). 'McIntosh' apple fruit thinning by benzyladenine in relation to seed number and endogenous cytokinin level in fruit and leaves. Scientia Horticulturae, 86, 127-134

Zabadal, T. J., and Bukovac, M. J. (2006). Effect of CPPU on fruit development of selected seedless and seeded grape cultivars. HortScience, 41(1), 154-157.

Zhang C, Tanabe K, Tani H, Nakajima H, Mori M, Sakuno E (2007a) Biologically active gibberellins and $\mathrm{ABA}$ in fruit of two late-maturing Japanese pear (Pyrus pyrifolia Nakai) cultivars with contrasting fruit size. J Am Soc Hort Sci 132:452-458.

Zhang, C., and Whiting, M. D. (2011). Improving 'Bing'sweet cherry fruit quality with plant growth regulators. Scientia Horticulturae, 127(3), 341-346.

Zhang, C., Lee, U., and Tanabe, K. (2008). Hormonal regulation of fruit set, parthenogenesis induction and fruit expansion in Japanese pear. Plant Growth Regulation, 55(3), 231.

\section{How to cite this article:}

Anubhav Biswal and Chandan Kumar Rout. 2020. Effect of Cytokinin on Fruit Crops. Int.J.Curr.Microbiol.App.Sci. 9(11): 2896-2903. doi: https://doi.org/10.20546/ijcmas.2020.911.351 